\title{
Biological Properties of a Citral-Enriched Fraction of Citrus limon Essential Oil
}

\author{
Marzia Pucci ${ }^{1,+}$, Stefania Raimondo ${ }^{1,+}\left(\mathbb{0}\right.$, Chiara Zichittella ${ }^{1}$, Vincenza Tinnirello ${ }^{2}$, \\ Valeria Corleone ${ }^{2}$, Gioacchino Aiello ${ }^{2}$, Marta Moschetti ${ }^{1} \mathbb{D}$, Alice Conigliaro ${ }^{1}$, \\ Simona Fontana ${ }^{1, *(D)}$ and Riccardo Alessandro ${ }^{1}$ (D) \\ 1 Department of Biomedicine, Neuroscience and Advanced Diagnostics (Bi.N.D), \\ Section of Biology and Genetics, University of Palermo, 90133 Palermo, Italy; marzia.pucci@unipa.it (M.P.); \\ stefania.raimondo@unipa.it (S.R.); zichy95.cz@gmail.com (C.Z.); marta.moschetti@unipa.it (M.M.); \\ alice.conigliaro@unipa.it (A.C.); riccardo.alessandro@unipa.it (R.A.) \\ 2 Agrumaria Corleone s.p.a., Via S. Corleone, 12-Zona Ind. Brancaccio, 90124 Palermo, Italy; \\ vincenzatinni@gmail.com (V.T.); vacorleone@agrumariacorleone.com (V.C.); \\ gaiello@agrumariacorleone.com (G.A.) \\ * Correspondence: simona.fontana@unipa.it; Tel.: +39-09123865731 \\ + These authors contributed equally to this work.
}

Received: 17 August 2020; Accepted: 11 September 2020; Published: 14 September 2020

check for updates

\begin{abstract}
Lemon essential oil (LEO) is a well-known flavoring agent with versatile biological activities. In the present study, we have isolated and characterized four citral-enriched fractions of winter LEO. We reported that in murine and human macrophages the pre-treatment with a mix of these fractions (Cfr-LEO) reduces the expression of the pro-inflammatory cytokines TNF- $\alpha$, IL-1 $\beta$, and IL- 6 induced by LPS. In addition, Cfr-LEO counteracts LPS-induced oxidative stress, as shown by the increase in the GSH/GSSG ratio in comparison to cells treated with LPS alone. Overall, the results reported here encourage the application of EO fractions, enriched in citral, in the nutraceutical industry, not only for its organoleptic properties but also for its protective action against inflammation and oxidative stress.
\end{abstract}

Keywords: Citrus limon (L.) Osbeck; essential oil; citral; nutraceuticals; inflammation; oxidative stress

\section{Introduction}

Essential oils (EOs), also called "volatile odoriferous oil", are concentrated aromatic liquids of a combination of volatile compounds that can be extracted from different parts of the plant, for example, leaves, peels, barks, flowers, buds, seeds, twigs, and roots. Different isolation methods have been described, among which steam distillation [1-3].

The genus Citrus, one of the most important taxonomic subunits of the family Rutaceae, includes approximately 17 species of plants that produce some of the most cultivated fruits in the world. Among them, considering their significative content, the species most used for EO production are lemons (Citrus limon (L.) Osbeck), oranges (Citrus sinensis (L.) Osbeck), grapefruits (Citrus paradisi Macfad), both mandarins and tangerines (Citrus reticulata Blanco), and various limes (mainly Citrus Aurantifolia (Christm.) Swingle) [4]. The main components of the C. limon EO (LEO) are represented by monoterpenoids [5-7]. In particular, LEO is a complex mixture of limonene, $\gamma$-terpinene, citral, linalool, $\beta$-caryophyllene, $\alpha$-pinene, and $\beta$-pinene [8].

Linalool, $\beta$-caryophyllene, and limonene possess anti-inflammatory effects [9-11]; instead, $\alpha$-pinene and $\beta$-pinene exert antioxidant effects by reducing nitric oxide production [12].

Moreover, citral, a mixture of the two aldehydes geranial and neral, which represents one of the main bioactive components of lemon oil (65-85\%), is known to possess various medicinal properties 
as inhibiting oxidant activity, nuclear factor kappa B (NF-kB) activation, and cyclooxygenase-2 (COX-2) expression. Katsukawa M. et al., showed that citral, in human macrophage-like U937 cells, induces expression of PPAR $\alpha$ and $-\gamma$ responsive genes and suppressed both LPS-induced COX-2 mRNA and protein expression in a PPAR $\gamma$-dependent manner [13]. Bouzenna H. et al. showed antioxidant effects of citral in rat small intestine epithelial cells, suggesting that citral can protect against aspirin-induced oxidative stress [14]. Interestingly, citral also has a significant effect in cancer prevention and treatment [15]; for example, hepatocarcinogenesis in rats was inhibited by lemongrass oil with a high content of citral [16]. Belusamy et al. also demonstrated that citral inhibited cell viability, proliferation, and clonogenic potential of prostate cancer cells by targeting key players of fatty acid biosynthesis [17].

Furthermore, citral mainly contributes to lemon flavor and for this reason, it is usually applied in the nutraceutical industry, which today is extremely interested in finding innovative solutions to obtain plant derivates with beneficial properties, to add to their existing products like food, beverages, and cosmetics.

Increasing population aging is unfortunately associated with the occurrence of age-related and inflammatory-based disorders. The relationship between oxidative stress and chronic inflammation is well known from the literature; in particular, reactive oxygen species (ROS) disrupts cell signaling, alters the metabolism of arachidonic acid, promotes or enhances airway and systemic inflammation [18]. Among inflammatory and immune effector cell types, macrophages play a crucial role in the immune response, producing both pro-inflammatory cytokines and other inflammatory mediators [19], for example, tumor necrosis factor $\alpha$ (TNF- $\alpha$ ), interleukin-1 $\beta$ (IL-1 $\beta$ ), IL-6. To date, pro-inflammatory and pro-oxidant regulators are considered important targets for the development of therapeutic strategies.

Different studies focused their attention on developing inhibitors from natural resources to prevent or alleviate chronic inflammatory conditions that can be used with minimal side effects.

According to the literature, LEO has versatile therapeutic activities on the digestive apparatus and the cardiovascular, nervous, and immune systems [20-31]. To date, most studies are centered on the functional analysis of whole LEO, highlighting its antioxidant and anti-inflammatory properties specifically related to the presence of linalool [11] and limonene [20]. Less consideration has been given to the biological properties of the fractions obtained from whole oil; in fact, the few available information is mainly focused on the isolation techniques and the molecular profiling description [32-36], rather than on the functional role of the fractions [37-39].

This study aimed to evaluate the anti-inflammatory and antioxidant activity of citral-enriched fractions of $C$. limon EO (Cfr-LEO) that, for their improved aroma profile, could have great commercial importance as natural food additives. With this purpose, C. limon EO was obtained by cold-pressed extraction from winter fruit and the Cfr-LEO isolated by chromatographic technique. The effects of Cfr-LEO were investigated on LPS-stimulated murine and human macrophages.

\section{Materials and Methods}

\subsection{Purification of Enriched Fractions from Citrus limon L. Essential Oil}

C. limon essential oil (LEO) was recovered by cold-pressed extraction mechanical process from the peels of winter fruits at the company Agrumaria Corleone S.P.A. (Palermo, Italy).

After cold dewaxing at $-20{ }^{\circ} \mathrm{C}$ for $48 \mathrm{~h}$ and subsequent filtration through a paper filter with 10-micron pores, LEO was fractionated by a newly developed adsorption column chromatography. Some volumes of essential oil flowed through the chromatographic column filled with a particular type of stationary phase under the following operating conditions: pressure: atmospheric; temperature: $25^{\circ} \mathrm{C}$; flow: $3 \mathrm{~mL} / \mathrm{min}$. This newly developed method allowed the collections of fractions enriched with the main aromatic compounds present in C. limon essential oil, based on their affinity with the 
stationary phase. Other technical details cannot here be reported and described since to date are covered by trade secrets.

\subsection{Gas Chromatography (GC-MS and GC-FID) Analyses}

The composition of volatile constituents of the essential oil was analyzed with Agilent $6890 \mathrm{~N}$ Network gas chromatographic (GC) equipped with Agilent 5973 mass spectrometer (Agilent Technologies Inc., Santa Clara, CA, USA) with a DB-5MS fused silica column (30 m $\times 0.25 \mathrm{~mm}$ ID, film thickness $0.25 \mu \mathrm{m}$, Agilent Technologies Inc., Saint Clara, CA, USA). The oven program started with an initial temperature of $75^{\circ} \mathrm{C}$ held for $9 \mathrm{~min}$, then the oven temperature was heated at $4{ }^{\circ} \mathrm{C} / \mathrm{min}$ to $120^{\circ} \mathrm{C}$ and after at $5{ }^{\circ} \mathrm{C} / \mathrm{min}$ to $310^{\circ} \mathrm{C}$ for $15 \mathrm{~min}$. The source temperature was $230^{\circ} \mathrm{C}$, quadrupole temperature was $150{ }^{\circ} \mathrm{C}$, injector and detector were 250 and $280^{\circ} \mathrm{C}$, respectively. The carrier gas was helium adjusted to a linear velocity of $42 \mathrm{~cm} / \mathrm{s}$. Samples were prepared by diluting in hexane in a ratio of 1:10. Samples were injected $(0.2 \mu \mathrm{L})$ with a split ratio of 1:50. The identification of essential oil volatile components was performed by comparison of their mass spectra with a NIST MS Search and Wiley 138 mass spectral library, as well as with literature data.

The GC-FID analysis of the EO was performed with GC Agilent 7890 A (Agilent Technologies Inc., Santa Clara, CA, USA) equipped with a non-polar DB-5 (Agilent Technologies Inc., Santa Clara, CA, USA) capillary column (length: $20 \mathrm{~m} ; 100 \mu \mathrm{m}$ internal diameter; film thickness $0.1 \mu \mathrm{m}$ ). The oven temperature program was set to $75^{\circ} \mathrm{C}$ for $3 \mathrm{~min}, 8^{\circ} \mathrm{C} / \mathrm{min}$ to $140{ }^{\circ} \mathrm{C}$ for $0 \mathrm{~min}, 30^{\circ} \mathrm{C} / \mathrm{min}$ to $310^{\circ} \mathrm{C}$ for $5 \mathrm{~min}$. The carrier gas was $\mathrm{H} 2$, at $0.80 \mathrm{~mL} / \mathrm{min}$ flow. Injector and detector temperatures were set at 280 and $350{ }^{\circ} \mathrm{C}$, respectively. Each EO sample was prepared by diluting it in isooctane in a ratio of 1:10. The injection volume was set at $0.2 \mu \mathrm{L}$. The GC-FID analysis of the samples allowed to obtain the relative percentage quantity of the single components contained in the analyzed samples. The value of each analyte is expressed as the percentage area of the peak with respect to the total composition of the EO obtained from the GC-FID analysis.

\subsection{Cell Culture and Treatment}

The murine macrophage RAW264.7 cell line was purchased from ATCC (Manassas, VA, USA). Cells were cultured in Dulbecco's modified Eagle's medium (DMEM) supplemented with 10\% Fetal Bovine Serum (FBS, Euroclone, UK), $2 \mathrm{mM}$ l-glutamine, $100 \mathrm{U} / \mathrm{mL}$ penicillin, and $100 \mu \mathrm{g} / \mathrm{mL}$ streptomycin (Euroclone, UK). The human monocyte THP-1 cell line was purchased from ATCC (Manassas, VA, USA). Cells were cultures in RPMI-1640 medium (Euroclone, UK) supplemented with $10 \%$ FBS, $2 \mathrm{mM} \mathrm{L-glutamine,} 100 \mathrm{U} / \mathrm{mL}$ penicillin, and $100 \mu \mathrm{g} / \mathrm{mL}$ streptomycin (Euroclone, UK). THP-1 monocytes were differentiated into M0 macrophages (THP-1 M0) as previously described [40]. In particular, cells were plated at $1 \times 10^{5}$ cells $/ \mathrm{mL}$ and incubated at $37^{\circ} \mathrm{C}$ with $5 \% \mathrm{CO}_{2}$ for $48 \mathrm{~h}$ in the presence of $50 \mathrm{ng} / \mathrm{mL}$ of Phorbol 12-myristate 13-acetate (PMA, Sigma-Aldrich, Saint Luis, MO, USA); subsequently, the conditioned medium containing PMA was removed and replaced with fresh medium for 3 days for cell recovering. Cells were then treated at different time points with various concentrations of LEO or Cfr-LEO, previously diluted in a solution consisting of $95 \%$ FBS and $5 \%$ DMSO. The biological assays reported in this manuscript have been carried out with 2 different batches of Cfr-LEO.

\subsection{MTT (3-[4,5-Dimethylthiazol-2-yl]-2,5 Diphenyl Tetrazolium Bromide) Assay}

Cell viability was determined by MTT assay as previously described [41]. RAW264.7 were seeded in triplicate at $3 \times 10^{3}$ cells per well in 96-well plates; $24 \mathrm{~h}$ post-seeding, cells were treated for 24 and $48 \mathrm{~h}$ with different concentrations of LEO or Cfr-LEO $(0.005 \%, 0.01 \%, 0.02 \%, 0.05 \%)$. THP- 1 M0 were seeded in triplicate at $2 \times 10^{4}$ cells per well in 48-well plates and treated for 24 and $48 \mathrm{~h}$ with LEO or Cfr-LEO $(0.005 \%, 0.01 \%, 0.02 \%, 0.05 \%)$. The absorbance was measured by ELISA reader at $540 \mathrm{~nm}$ (Microplate Reader, BioTek, Winooski, VT, USA). Values are expressed as a percentage of cell growth versus control (untreated cells). 


\subsection{Measurement of Cytotoxicity in Cells Exposed to Cfr-LEO Treatment}

For the detection of cytotoxicity, the CellTox ${ }^{\mathrm{TM}}$ Green Cytotoxicity Assay (Catalog number G8741, Promega, Madison, WI, USA) was used. RAW264.7 were cultured in triplicate at $5 \times 10^{3}$ cells per well into white-walled, opaque assay 96 well plates; $24 \mathrm{~h}$ post-seeding, cells were treated for 24 and $48 \mathrm{~h}$ with different concentrations of LEO or Cfr-LEO (0.005\%, $0.01 \%, 0.02 \%, 0.05 \%)$. THP-1 M0 cells were seeded in triplicate at $1 \times 10^{4}$ cells per well into white-walled, opaque assay 96 well plates and treated for 24 and $48 \mathrm{~h}$ with LEO or Cfr-LEO $(0.005 \%, 0.01 \%, 0.02 \%, 0.05 \%)$. Changes in membrane integrity that occur as a result of cell death were measured by the CellTox ${ }^{\mathrm{TM}}$ Green Cytotoxicity Assay following the manufactures instructions. The fluorescence, proportional to cytotoxicity, was measured by Glomax (Promega).

\subsection{RNA Isolation and Real-Time PCR}

Levels of IL1 $\beta$, IL6, and TNF $\alpha$ were measured by Real-time PCR. RAW264.7 cells were seeded at $5 \times 10^{4}$ cells per well in 12-well plates; $24 \mathrm{~h}$ after seeding, cells were treated for $2 \mathrm{~h}$ with different concentrations of LEO or Cfr-LEO $(0.005 \%, 0.01 \%, 0.02 \%)$ and then exposed to LPS $(500 \mathrm{ng} / \mathrm{mL})$ for $6 \mathrm{~h}$, without oil removal. THP-1 M0 cells were seeded at $1 \times 10^{5}$ cells per well in 12-well plates and treated for $2 \mathrm{~h}$ with LEO or Cfr-LEO $(0.005 \%, 0.01 \%)$ before their exposure to LPS $(1 \mu \mathrm{g} / \mathrm{mL})$ for $6 \mathrm{~h}$, without oil removal. Levels of BAX, BAD, and BCL-2 were measured by Real-Time PCR in RAW264.7 cells treated with $0.01 \%$ and $0.02 \%$ of Cfr-LEO for 24 and $48 \mathrm{~h}$. RNA was isolated using the commercially available Illustra RNA spin Mini Isolation Kit (GE Healthcare, Little Chalfont, Buckinghamshire, UK), according to manufacturer's instructions. Total RNA from RAW264.7 or human THP-1 M0 cells was reverse transcribed to cDNA using the High Capacity cDNA Reverse Transcription kit (Applied Biosystems, Foster City, CA, USA). For quantitative SYBR Green Real-time PCR, the reaction was carried out in a total volume of $20 \mu \mathrm{L}$ containing $2 X$ SYBR Green I Master Mix (Applied Biosystems), $2 \mu \mathrm{L}$ of cDNA, and $300 \mathrm{nM}$ forward and reverse primers. The oligonucleotides used are reported in the Table 1.

Table 1. Oligonucleotides used in Real-Time PCR analysis

\begin{tabular}{ccc}
\hline Gene & Forward & Reverse \\
\hline Murine & & \\
\hline GAPDH & CCCAGAAGACTGTGGATGG & CAGATTGGGGGTAGGAACAC \\
BCL-2 & GGACTTGAAGTGCCATTGGT & AGCCCCTCTGTGACAGCTTA \\
BAX & CTGCAGAGGATGATTGCTGA & GATCAGCTCGGGCACTTTAG \\
BAD & GAGTCGCCACAGTTCGTACC & GGTCCCATCGCACCTAACG \\
IL6 & GAGGATACCACTCCCAACAGACC & AAGTGCATCATCGTTGTTCATACA \\
TNF $\alpha$ & CACGTCGTAGCAAACCACCAAGTGGA & TGGGAGTAGACAAGGTACAACCC \\
IL1 $\beta$ & CAACCAACAAGTGATATTCTCCATG & GATCCAACACTCTCCAGCTGCA \\
\hline Human & & \\
\hline GAPDH & ATGGGGAAGGTGAAGGTCG & GGGTCATTGATGGCAACAATAT \\
IL6 & GGTACATCCTCGACGGCATCT & GTGCCTCTTTGCTGCTTTCAC \\
TNF $\alpha$ & CCAGGCAGTCAGATCATCTTCTC & AGCTGGTTATCTCTCAGCTCCAC \\
IL1 $\beta$ & ACAGATGAAGTGCTCCTTCCA & GTCGGAGATTCGTAGCTGGAT \\
\hline
\end{tabular}

Real-time PCR was performed in 48-well plates using the Step-One Real-Time PCR System (Applied Biosystems). Relative changes in gene expression between control and treated samples were determined using the $\Delta \Delta \mathrm{Ct}$ method. Levels of the target transcript were normalized to a GAPDH endogenous control, constantly expressed in all samples $(\Delta \mathrm{Ct})$. For $\Delta \Delta \mathrm{Ct}$ values, additional subtractions were performed between treated samples and control $\Delta \mathrm{Ct}$ values. Final values were expressed as fold change. 


\subsection{Enzyme Linked ImmunoSorbent Assay (ELISA) Assays}

The amounts of IL6 and TNF $\alpha$ in culture supernatants were determined by using mouse IL6- and TNF $\alpha$ - specific ELISA kits (Thermo Fisher Scientific, Waltham, MA USA).

RAW264.7 cells were seeded at $5 \times 10^{4}$ cells per well in 12-well plates; $24 \mathrm{~h}$ after seeding, cells were treated for $2 \mathrm{~h}$ with $0.01 \%$ of Cfr-LEO and then exposed to LPS $(500 \mathrm{ng} / \mathrm{mL})$ for $6 \mathrm{~h}$, without oil removal. At the end of the experimental time, the conditioned medium was collected and centrifuged to remove cellular debris. The ELISA assays were then performed according to the manufacturer's instructions.

\subsection{Measurement of GSH and GSSG in Cells Exposed to Cfr-LEO Treatment}

To detect and quantify total glutathione (GSH + GSSG), GSSG and GSH-to-GSSG ratios in THP-1 M0 cells treated with Cfr-LEO, the bioluminescent GSH/GSSG-Glo Assay kit (Catalog number V6611, Promega, Madison, WI, USA) was used. Cells were seeded at $1 \times 104$ cells per well into white-walled, opaque assay 96 well plates, treated for $2 \mathrm{~h}$ with Cfr-LEO $(0.005 \%$ and $0.01 \%)$, and then exposed to LPS $(1 \mu \mathrm{g} / \mathrm{mL})$ for $6 \mathrm{~h}$, without oil removal. After incubation, the bioluminescent GSH/GSSG-Glo Assay kit was used following the manufacturer's instructions. Cells were lysed by shaking with an equal volume of either total or oxidized glutathione reagent for $5 \mathrm{~min}$, and then, cell lysates were incubated for $30 \mathrm{~min}$ with $50 \mu \mathrm{L}$ of luciferin generation reagent. After the addition of $100 \mu \mathrm{L}$ of luciferin detection reagent, plates were equilibrated for $15 \mathrm{~min}$ at room temperature. The luminescence (net relative luminescence unit, RLU) was measured by Glomax (Promega). The results were expressed as the GSH/GSSG ratio, calculated as follows: GSH/GSSG ratio = (Net total glutathione RLU-Net GSSG RLU)/(Net GSSG RLU/2).

\subsection{Statistical Analysis}

Data are represented as means $\pm \mathrm{SD}$. Comparisons were made using a Student's $t$-test. Values were considered statistically significant when $p \leq 0.05$.

\section{Results and Discussion}

\subsection{Characterization of the Fractions Isolated from Citrus limon EO}

To exploit at best the use of LEO as a flavoring agent, an aim is to obtain fractions enriched in compounds responsible for the lemon aroma. With this purpose, within this study, starting from the whole LEO extracted from winter fruits, we isolated four citral-enriched fractions with an enhanced lemon flavor.

Overall, 43 compounds, representing more than $99 \%$ of the total volatiles, were analyzed by GC-FID in the whole LEO and in each fraction (Fr). These compounds are listed in Table 2 where the corresponding Retention time and the \% are reported for whole LEO and for 4 out of the 16 isolated fractions, Fr13, Fr 14, Fr15, and Fr16. These fractions were selected since they were the only in which neral and geranial (n 26 and 28 in Table 2), the two isomers of citral considered the essence of the lemon aroma, were enriched.

Table 3 summarizes the percentage trend of the main chemical classes of EOs (Monoterpenes, Aldehydes, Esters, Sesquiterpenes, Aliphatic Alcohols, Sesquiterpene Alcohols). Reported data show that within the class of aldehydes, the citral (a mixture of geranial and neral) is the major constituent and has an increment of about $30 \%$ in each of the four selected fractions in comparison to whole LEO; no differences were revealed for Monoterpenes, Sesquiterpenes, Aliphatic Alcohols, and Sesquiterpene Alcohols while there was a decrement of Esters. Internal olfactory panel tests have demonstrated that the fractions Fr13, Fr14, Fr15, and Fr16 enhanced their aroma properties in comparison to whole LEO, thus indicating that the $30 \%$ increase of citral determinates better olfactory characteristics. 
Table 2. Volatile compounds identified in winter lemon essential oil (EO) (whole LEO) and in the selected fractions (Fr13, Fr14, Fr15, Fr16).

\begin{tabular}{|c|c|c|c|c|c|c|c|c|c|c|c|}
\hline \multirow{2}{*}{ No } & \multirow{2}{*}{ VOLATILE COMPOUND } & \multicolumn{2}{|c|}{ WHOLE LEO } & \multicolumn{2}{|c|}{ Fr13 } & \multicolumn{2}{|c|}{ Fr14 } & \multicolumn{2}{|c|}{ Fr15 } & \multicolumn{2}{|c|}{ Fr16 } \\
\hline & & $\mathrm{Rt}^{\mathrm{a}}$ & Area $(\%)^{b}$ & $\mathbf{R t}$ & Area (\%) & Rt & Area $(\%)$ & Rt & Area $(\%)$ & Rt & Area $(\%)$ \\
\hline 1 & $\alpha$-Thujene & 1.688 & 0.43 & 1.674 & 0.42 & 1.676 & 0.42 & 1.675 & 0.42 & 1.675 & 0.42 \\
\hline 2 & $\alpha$-Pinene & 1.757 & 1.81 & 1.743 & 1.79 & 1.745 & 1.79 & 1.744 & 1.79 & 1.744 & 1.79 \\
\hline 3 & Camphene & 1.892 & 0.06 & 1.875 & 0.05 & 1.878 & 0.06 & 1.876 & 0.05 & 1.877 & 0.05 \\
\hline 4 & Sabinene & 2.132 & 1.83 & 2.112 & 1.81 & 2.115 & 1.81 & 2.113 & 1.81 & 2.114 & 1.81 \\
\hline 5 & $\beta$-Pinene & 2.197 & 10.88 & 2.178 & 10.81 & 2.181 & 10.80 & 2.18 & 10.80 & 2.18 & 10.79 \\
\hline 6 & Myrcene & 2.309 & 1.57 & 2.286 & 1.56 & 2.29 & 1.56 & 2.288 & 1.56 & 2.289 & 1.56 \\
\hline 7 & Octanal & 2.447 & 0.07 & 2.419 & 0.06 & 2.422 & 0.06 & 2.419 & 0.06 & 2.421 & 0.06 \\
\hline 8 & Phellandrene & 2.504 & 0.05 & 2.477 & 0.04 & 2.481 & 0.04 & 2.478 & 0.04 & 2.48 & 0.04 \\
\hline 9 & $\delta$-3-Carene & 2.593 & 0.01 & 2.566 & 0.01 & 2.572 & 0.01 & 2.57 & 0.01 & 2.571 & 0.01 \\
\hline 10 & $\alpha$-Terpinene & 2.683 & 0.21 & 2.654 & 0.20 & 2.661 & 0.20 & 2.657 & 0.20 & 2.657 & 0.20 \\
\hline 11 & Limonene & 2.982 & 67.10 & 2.965 & 67.09 & 2.972 & 67.09 & 2.971 & 67.07 & 2.972 & 67.05 \\
\hline 12 & (Z)- $\beta$-Ocimene & 3.063 & 0.05 & 3.008 & 0.05 & 3.014 & 0.05 & 3.012 & 0.05 & 3.013 & 0.05 \\
\hline 13 & (E)- $\beta$-Ocimene & 3.198 & 0.12 & 3.163 & 0.12 & 3.17 & 0.12 & 3.166 & 0.12 & 3.168 & 0.12 \\
\hline 14 & $\gamma$-Terpinene & 3.434 & 9.32 & 3.404 & 9.27 & 3.411 & 9.27 & 3.408 & 9.26 & 3.41 & 9.26 \\
\hline 15 & Cis-Sabinene hydrate & 3.556 & 0.04 & 3.522 & 0.01 & 3.52 & 0.01 & 3.513 & 0.02 & 3.515 & 0.03 \\
\hline 16 & Octanol & 3.654 & 0.01 & 3.612 & 0.00 & 3.609 & 0.00 & 3.606 & 0.00 & 3.608 & 0.00 \\
\hline 17 & Terpinolene & 3.936 & 0.41 & 3.893 & 0.41 & 3.9 & 0.40 & 3.895 & 0.40 & 3.898 & 0.40 \\
\hline 18 & Trans-Sabinene hydrate & 4.132 & 0.03 & 4.1 & - & 4.1 & - & 4.1 & - & 4.1 & - \\
\hline 19 & Linalool & 4.158 & 0.13 & 4.109 & 0.13 & 4.115 & 0.14 & 4.109 & 0.15 & 4.112 & 0.15 \\
\hline 20 & Nonanal & 4.228 & 0.11 & 4.179 & 0.11 & 4.185 & 0.10 & 4.18 & 0.10 & 4.183 & 0.10 \\
\hline 21 & Citronellal & 5.186 & 0.10 & 5.134 & 0.10 & 5.14 & 0.10 & 5.134 & 0.10 & 5.137 & 0.10 \\
\hline 22 & Terpinen-4-ol & 5.65 & 0.03 & 5.596 & 0.03 & 5.601 & 0.03 & 5.594 & 0.03 & 5.598 & 0.03 \\
\hline 23 & $\alpha$-Terpineol & 5.917 & 0.17 & 5.724 & - & 5.729 & 0.01 & 5.863 & 0.03 & 5.865 & 0.05 \\
\hline 24 & Decanal & 6.223 & 0.04 & 6.171 & 0.03 & 6.177 & 0.03 & 6.17 & 0.03 & 6.174 & 0.03 \\
\hline 25 & Nerol+Citronellol & 6.678 & 0.05 & 6.633 & 0.00 & 6.629 & 0.01 & 6.622 & 0.02 & 6.625 & 0.03 \\
\hline 26 & Neral & 6.905 & 1.00 & 6.854 & 1.35 & 6.86 & 1.33 & 6.854 & 1.31 & 6.858 & 1.31 \\
\hline 27 & Geraniol & 7.192 & 0.05 & 7.14 & - & 7.14 & - & 7.148 & - & 7.147 & 0.01 \\
\hline 28 & Geranial & 7.483 & 1.72 & 7.435 & 2.19 & 7.442 & 2.21 & 7.437 & 2.21 & 7.44 & 2.21 \\
\hline 29 & Undecanal & 8.15 & 0.02 & 8.096 & 0.02 & 8.102 & 0.02 & 8.096 & 0.02 & 8.1 & 0.02 \\
\hline 30 & Methyl geranate & 8.682 & 0.02 & 8.628 & 0.03 & 8.634 & 0.03 & 8.628 & 0.03 & 8.632 & 0.03 \\
\hline 31 & Citronellyl acetate & 9.006 & 0.03 & 8.951 & 0.03 & 8.956 & 0.03 & 8.951 & 0.03 & 8.955 & 0.03 \\
\hline
\end{tabular}


Table 2. Cont

\begin{tabular}{|c|c|c|c|c|c|c|c|c|c|c|c|}
\hline \multirow{2}{*}{ No } & \multirow{2}{*}{ VOLATILE COMPOUND } & \multicolumn{2}{|c|}{ WHOLE LEO } & \multicolumn{2}{|c|}{ Fr13 } & \multicolumn{2}{|c|}{ Fr14 } & \multicolumn{2}{|c|}{ Fr15 } & \multicolumn{2}{|c|}{ Fr16 } \\
\hline & & $\mathrm{Rt}^{\mathrm{a}}$ & Area $(\%)^{b}$ & Rt & Area (\%) & Rt & Area (\%) & Rt & Area (\%) & Rt & Area $(\%)$ \\
\hline 32 & Neryl acetate & 9.203 & 0.46 & 9.15 & 0.51 & 9.155 & 0.49 & 9.15 & 0.49 & 9.154 & 0.48 \\
\hline 33 & Geranyl acetate & 9.54 & 0.31 & 9.486 & 0.35 & 9.491 & 0.33 & 9.486 & 0.33 & 9.49 & 0.33 \\
\hline 34 & $\beta$-Caryophyllene & 10.105 & 0.23 & 10.05 & 0.23 & 10.056 & 0.23 & 10.051 & 0.23 & 10.055 & 0.23 \\
\hline 35 & Bergamotene & 10.409 & 0.31 & 10.357 & 0.32 & 10.362 & 0.31 & 10.357 & 0.32 & 10.361 & 0.32 \\
\hline 36 & Valencene & 11.325 & 0.02 & 11.275 & 0.02 & 11.279 & 0.02 & 11.276 & 0.02 & 11.279 & 0.02 \\
\hline 37 & Bicyclogermacrene & 11.374 & 0.05 & 11.325 & 0.04 & 11.328 & 0.05 & 11.325 & 0.04 & 11.328 & 0.04 \\
\hline 38 & (Z)- $\alpha$-Bisabolene & 11.475 & 0.05 & 11.432 & 0.04 & 11.435 & 0.04 & 11.432 & 0.04 & 11.435 & 0.04 \\
\hline 39 & $\beta$-Bisabolene & 11.553 & 0.48 & 11.512 & 0.48 & 11.516 & 0.48 & 11.513 & 0.48 & 11.515 & 0.48 \\
\hline 40 & $\gamma$-Elemene & 11.931 & 0.02 & 11.896 & 0.02 & 11.899 & 0.02 & 11.896 & 0.02 & 11.898 & 0.02 \\
\hline 41 & 2-Norbornarol & 12.859 & 0.02 & 12.83 & 0.02 & 12.832 & 0.02 & 12.831 & 0.02 & 12.831 & 0.02 \\
\hline 42 & Campherenol & 12.947 & 0.02 & 12.919 & 0.02 & 12.92 & 0.02 & 12.919 & 0.02 & 12.92 & 0.03 \\
\hline 43 & Bisabolol & 13.046 & 0.02 & 13.02 & 0.03 & 13.02 & 0.03 & 13.02 & 0.03 & 13.02 & 0.03 \\
\hline
\end{tabular}

${ }^{a}$ Rt: Retention time in minutes ${ }^{\mathrm{b}}$ Area (\%): percentage obtained by FID peak-area normalization. The values reported in the table are representative of one of the three replicates.

Table 3. The percentage trend of the main chemical classes of identified in winter lemon EO (whole LEO) and its fractions (Fr13, Fr14, Fr15, Fr16). Citral (in red) is more concentrated in the fractions than in the starting whole EO. The values reported in the table are representative of one of the three replicates.

\begin{tabular}{|c|c|c|c|c|c|}
\hline Chemical Classes & Whole LEO (\%) & Fr $13(\%)$ & Fr $14(\%)$ & Fr $15(\%)$ & Fr $16(\%)$ \\
\hline Monoterpenes & 93.9 & 93.65 & 93.64 & 93.61 & 93.6 \\
\hline Total Aldehydes & 3.06 & 3.87 & 3.85 & 3.84 & 3.84 \\
\hline citral & 2.73 & 3.54 & 3.53 & 3.52 & 3.52 \\
\hline (geranial + neral) & $(1.72+1)$ & $(2.19+1.35)$ & $(2.21+1.33)$ & $(2.21+1.31)$ & $(2.21+1.31)$ \\
\hline Aldehydes minus citral & 0.33 & 0.33 & 0.32 & 0.32 & 0.32 \\
\hline Sesquiterpenes & 1.16 & 1.15 & 1.15 & 1.15 & 1.15 \\
\hline Esters & 0.82 & 0.92 & 0.88 & 0.87 & 0.87 \\
\hline Aliphatic Alcohols & 0.43 & 0.17 & 0.20 & 0.24 & 0.28 \\
\hline Sesquiterpene Alcohols & 0.06 & 0.07 & 0.07 & 0.07 & 0.07 \\
\hline
\end{tabular}


We found that among the three technical replicates of the fractionation process, the percentage of compounds showing a coefficient of variation (CV\%) $\leq 5$ was 70\% for Fr13, 72\% for Fr14, 55.8\% for Fr15, and $72 \%$ for Fr16 (Figure S1a) and in all fractions, CV\% higher than 20\% was not found for any compound. Overall, these results highlighted that the fractionation process used in this study ensures high reproducibility. Moreover, as reported in Figure S1b, among the four selected fractions, the percentage of the compounds including citral (specifically reported in Figure S1c) was comparable. Thus, according to the equivalent composition of these fractions, we decided to mix them to obtain a citral-enriched fraction of $C$. limon EO (Cfr-LEO), characterized by an increase in the aromatic level. In consideration of the interest that this enriched fraction may have in the food, beverage, and cosmetic industry, its biological effects were further evaluated.

\subsection{Evaluation of Macrophage Cell Viability after Cfr-LEO Exposure}

To obtain a comprehensive understanding of the doses to be further used, we carried out two complementary assays aimed at evaluating both cell viability and cell death.

The results in Figure 1a,b showed that cell treatment with $0.005 \%, 0.01 \%$, and $0.02 \%$ of Cfr-LEO for 24 and $48 \mathrm{~h}$ did not affect the RAW264.7 cell viability; instead, a significant decrease in RAW264.7cell viability after treatment with $0.05 \%$ for 24 and $48 \mathrm{~h}$ was observed at both time points. No significant decrease in THP- $1 \mathrm{M} 0$ cells viability after treatment for 24 and $48 \mathrm{~h}$ with all concentrations of Cfr-LEO tested was observed. At the same experimental conditions, whole LEO treatment affected both murine and human macrophage cell viability in a dose and time-dependent manner (Figure 1c,d).
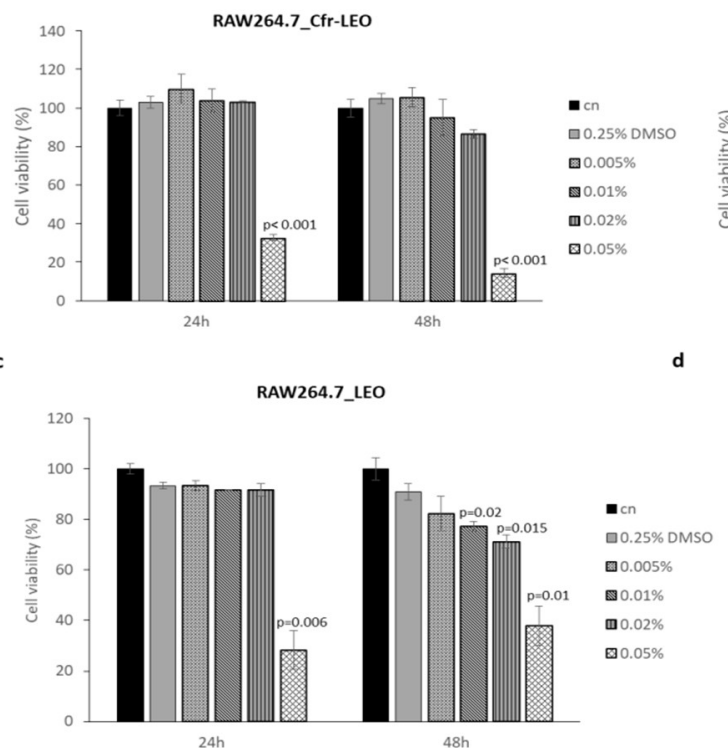
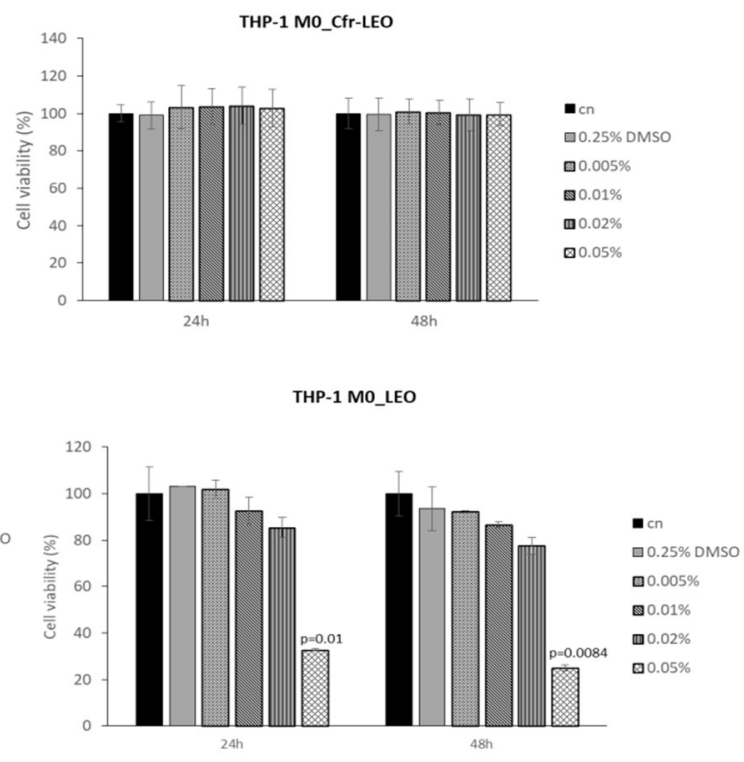

Figure 1. Evaluation of macrophage cell viability after Cfr-LEO and LEO exposure. (a) RAW264.7 and (b) THP-1 M0 cell viability was measured by MTT assay after 24 and $48 \mathrm{~h}$ of treatment with different concentrations of Cfr-LEO $(0.005 \%, 0.01 \%, 0.02 \%, 0.05 \%)$. The values were plotted as the percentage of cell viability versus untreated cells $(\mathrm{cn})$. Values are the mean $\pm \mathrm{SD}$ of two biological replicates, each carried out in technical quadruplicates. The statistical significance of the differences between two groups (cells treated with $0.05 \%$ of Cfr-LEO Vs cn) was analyzed using a two-tailed Student's t-test. (c) RAW264.7 and (d) THP-1 M0 cell viability were measured by MTT assay after 24 and $48 \mathrm{~h}$ of treatment with different concentrations of LEO $(0.005 \%, 0.01 \%, 0.02 \%, 0.05 \%)$. The values were plotted as the percentage of cell viability versus untreated cells (cn). Values are the mean \pm SD of two biological replicates, each carried out in technical triplicates. The statistical significance of the differences between the two groups (cells treated with LEO Vs cn) was analyzed using a two-tailed Student's $t$-test. 
Overall, the results indicate that Cfr-LEO did not exhibit any effect on cell viability at $0.005 \%, 0.01 \%$, and $0.02 \%$ concentrations for both cell lines tested; interestingly, on human macrophages, the same compound can be used even at higher concentrations, up to $0.05 \%$. Therefore, the concentrations of Cfr-LEO ranging from $0.005 \%$ to $0.02 \%$ were employed for subsequent experiments.

\subsection{Evaluation of Macrophage Cytotoxicity after EO Exposure}

THP-1 M0 and RAW264.7 cell lines changes in membrane integrity, that occur as a result of cell death, were measured to exclude cytotoxic effects of Cfr-LEO. Cytotoxicity of RAW264.7 cell lines after incubation for 24 and $48 \mathrm{~h}$ with different concentrations of Cfr-LEO $(0.005 \%, 0.01 \%, 0.02 \%, 0.05 \%)$ was evaluated, and the obtained data are presented in Figure 2a. Data showed that treatment with $0.005 \%, 0.01 \%$, and $0.02 \%$ for 24 and $48 \mathrm{~h}$ did not exhibit cytotoxic effects on RAW264.7 cell lines, while, consistent with cell viability assays, a significant increase in RAW264.7 cells toxicity was observed after exposure with $0.05 \%$.

a

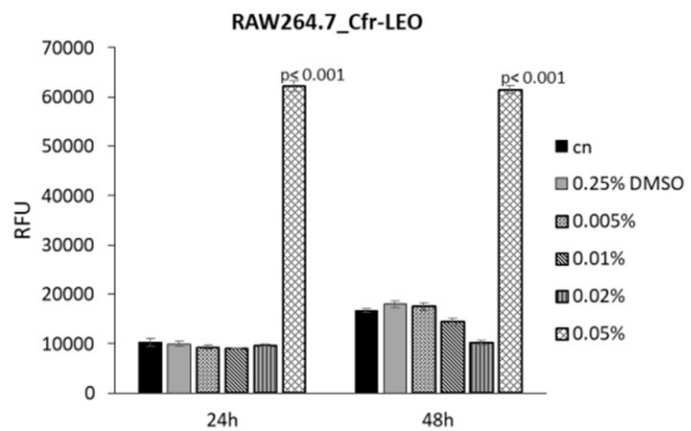

c

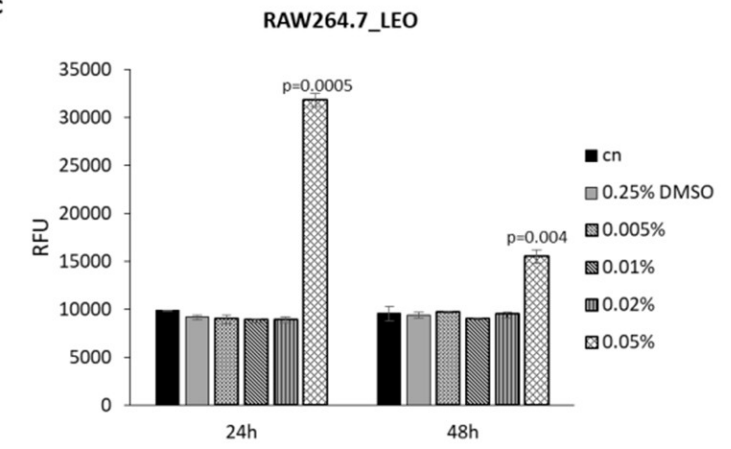

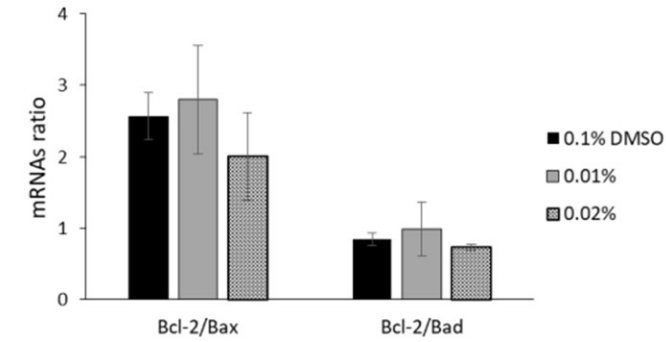

d

RAW264.7_LEO

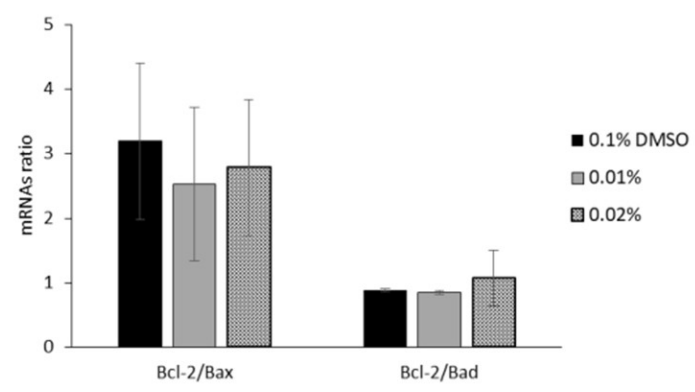

Figure 2. Evaluation of murine macrophage cytotoxicity after Cfr-LEO and LEO exposure. (a) RAW264.7 cell cytotoxicity was measured by CellTox Green Cytotoxicity Assay after 24 and $48 \mathrm{~h}$ of treatment with different concentrations of Cfr-LEO $(0.005 \%, 0.01 \%, 0.02 \%, 0.05 \%)$. Values are plotted as Relative Fluorescence Unit (RFU). Values are the mean \pm SD of two biological replicates, each carried out in technical duplicates. The statistical significance of the differences between two groups (cells treated with $0.05 \%$ of Cfr-LEO Vs cn) was analyzed using a two-tailed Student's $t$-test. (b) The effects of Cfr-LEO treatment $(0.01 \%, 0.02 \%)$ on Bcl-2, Bax and Bad transcription were assessed by qRT-PCR. Data are represented as $\mathrm{Bcl}-2 / \mathrm{Bax}$ and $\mathrm{Bcl}-2 / \mathrm{Bad}$ ratio. Values are the mean $\pm \mathrm{SD}$ of two biological replicates. (c) RAW264.7 cell cytotoxicity was measured by CellTox Green Cytotoxicity Assay after 24 and 48 h of treatment with different concentrations of LEO $(0.005 \%, 0.01 \%, 0.02 \%, 0.05 \%)$. Values are plotted as Relative Fluorescence Unit (RFU). Values are the mean \pm SD of two biological replicates, each carried out in technical triplicates. The statistical significance of the differences between two groups (cells treated with $0.05 \%$ LEO $V s$ cn) was analyzed using a two-tailed Student's $t$-test. (d) The effects of LEO treatment $(0.01 \%, 0.02 \%)$ on Bcl-2, Bax, and Bad transcription were assessed by qRT-PCR. Data are represented as Bcl-2/Bax (two biological replicates) and Bcl-2/Bad (three biological replicates) ratio. 
Several molecular factors such as Bcl-2, Bax, and Bad play a key role in the execution of cells apoptosis [42]. Therefore, Bcl-2, Bax, and Bad gene expression were determined at the transcriptional level in RAW264.7 cell line after incubation for $48 \mathrm{~h}$ with different concentrations $(0.01 \%$ and $0.02 \%)$ of Cfr-LEO. In particular, apoptotic gene expression was measured based on Bcl-2/Bax and Bcl-2/Bad ratio, and the obtained data are presented in Figure 2b. No modulation in the Bcl-2/Bax and Bcl-2/Bad ratio was observed in RAW264.7 cells treated with both concentrations of Cfr-LEO tested. We observed a comparable effect of whole LEO on RAW264.7 cell toxicity induction at $0.05 \%$ treatment (Figure 2c), as well as on apoptotic gene expression level (Figure 2d).

The cytotoxic effects of Cfr-LEO and whole LEO were further evaluated on THP-1 M0 cells. Interestingly, no significant increase in THP-1 M0 cells cytotoxicity after treatment for 24 and $48 \mathrm{~h}$ with all concentrations of Cfr-LEO tested was observed (Figure 3a), while whole LEO treatment significantly induced THP-1 cell toxicity at $0.02 \%$ and $0.05 \%$ at both time point analyzed (Figure $3 b$ ).

a

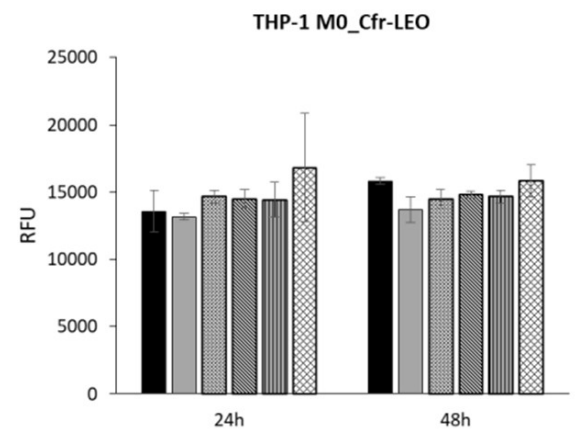

b

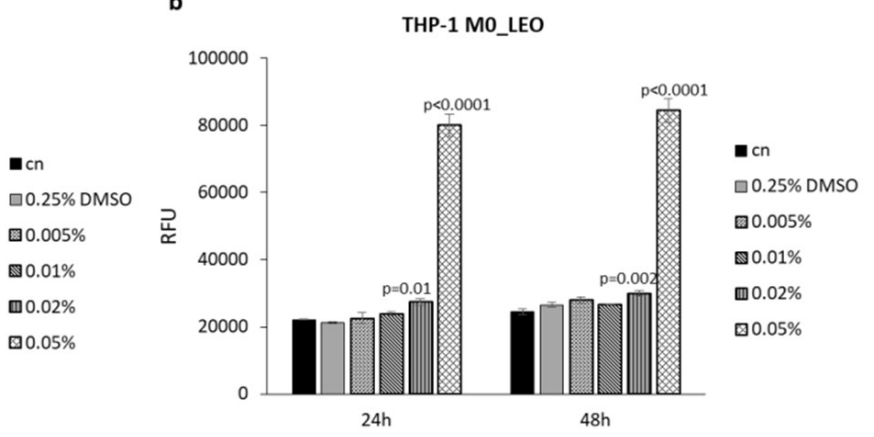

Figure 3. Evaluation of human macrophage cytotoxicity after Cfr-LEO and LEO exposure. (a) THP-1 M0 cell cytotoxicity was measured by CellTox Green Cytotoxicity Assay after 24 and $48 \mathrm{~h}$ of treatment with different concentrations of Cfr-LEO $(0.005 \%, 0.01 \%, 0.02 \%, 0.05 \%)$. Values are plotted as the Relative Fluorescence Unit (RFU). Cn: untreated cells. Values are the mean \pm SD of two biological replicates, each carried out in technical duplicates. (b) THP-1 M0 cell cytotoxicity was measured by CellTox Green Cytotoxicity Assay after 24 and $48 \mathrm{~h}$ of treatment with different concentrations of LEO $(0.005 \%, 0.01 \%, 0.02 \%, 0.05 \%)$. Values are plotted as the Relative Fluorescence Unit (RFU). Cn: untreated cells. Values are the mean \pm SD of two biological replicates, each carried out in technical triplicates.

Overall, these results, in line with the data on cell viability, confirmed that Cfr-LEO did not exhibit any cytotoxic effect at $0.005 \%, 0.01 \%$, and $0.02 \%$ for both cell lines tested. Therefore, these doses were selected for further analysis.

\subsection{Protective Effects of Cfr-LEO on LPS-Activated Macrophages}

The de-regulation of inflammatory homeostasis, in favor of its over-regulation, along with the increase in the pro-inflammatory cytokines is associated with the occurrence of age-related diseases and aging itself [43-45]. This phenomenon is known as "Inflammaging" [46,47] and is correlated to the increase of TNF- $\alpha$, IL-1 $\beta$, and IL-6. Therefore, enhancing the anti-inflammatory response of the organism is critical for healthy aging.

Citrus EOs have largely been described for their anti-inflammatory properties $[22,23,48]$ often related to the ability to induce a reduction of TNF $\alpha$, IL1 $\beta$, and IL6 levels [22,49]. Citrus medica EO, mostly containing limonene and $\gamma$-terpinene, reduced LPS-induced pro-inflammatory cytokines in murine macrophages; these effects occur simultaneously with the inhibition of the transcription factor NF-kB [49].

Macrophages play a key role in both specific and non-specific immune responses during inflammation [50]. Following activation by LPS, several pro-inflammatory cytokines are secreted and oxidative stress induced. Overproduction of these intermediaries is involved in different inflammatory 
diseases and cancer [51,52], indicating that the inhibition of macrophage activation could be an important target for inflammatory disease treatment.

To investigate whether Cfr-LEO exhibits protective effects against LPS-induced macrophage activation, we analyzed the effects of Cfr-LEO on the modulation of inflammatory mediators (IL6, IL1 $\beta$, and TNF $\alpha$ ) at the transcriptional level as well as on the GSH/GSSG ratio. In particular, as shown in Figure $4 \mathrm{a}$, the pre-treatment of RAW 264.7 for $2 \mathrm{~h}$ with each concentration of Cfr-LEO $(0.005 \%, 0.01 \%$, $0.02 \%$ ), before their exposure to LPS for $6 \mathrm{~h}$, significantly inhibited the production of pro-inflammatory mediators (IL6, IL1 $\beta$, and TNF $\alpha$ ) compared to the 6-h LPS-treated cells. Similarly, the pre-treatment of THP-1 M0 with Cfr-LEO $(0.005 \%, 0.01 \%)$ inhibited the production of LPS-induced pro-inflammatory mediators IL6 and, TNF $\alpha$, while we did not observe a reduction of IL1 $\beta$ Figure $4 \mathrm{~b}$. We observed a comparable effect of whole LEO in inhibiting the expression of inflammatory mediators in LPS-induced murine macrophages (Figure 4c), while, at the same doses whole LEO is not effective on human THP-1 macrophages (Figure 4d). The reduction of IL6 and TNF $\alpha$ in RAW264.7 pre-treated with $0.01 \%$ of Cfr-LEO, before exposure to LPS, was also confirmed at the protein level (Figure 4e).
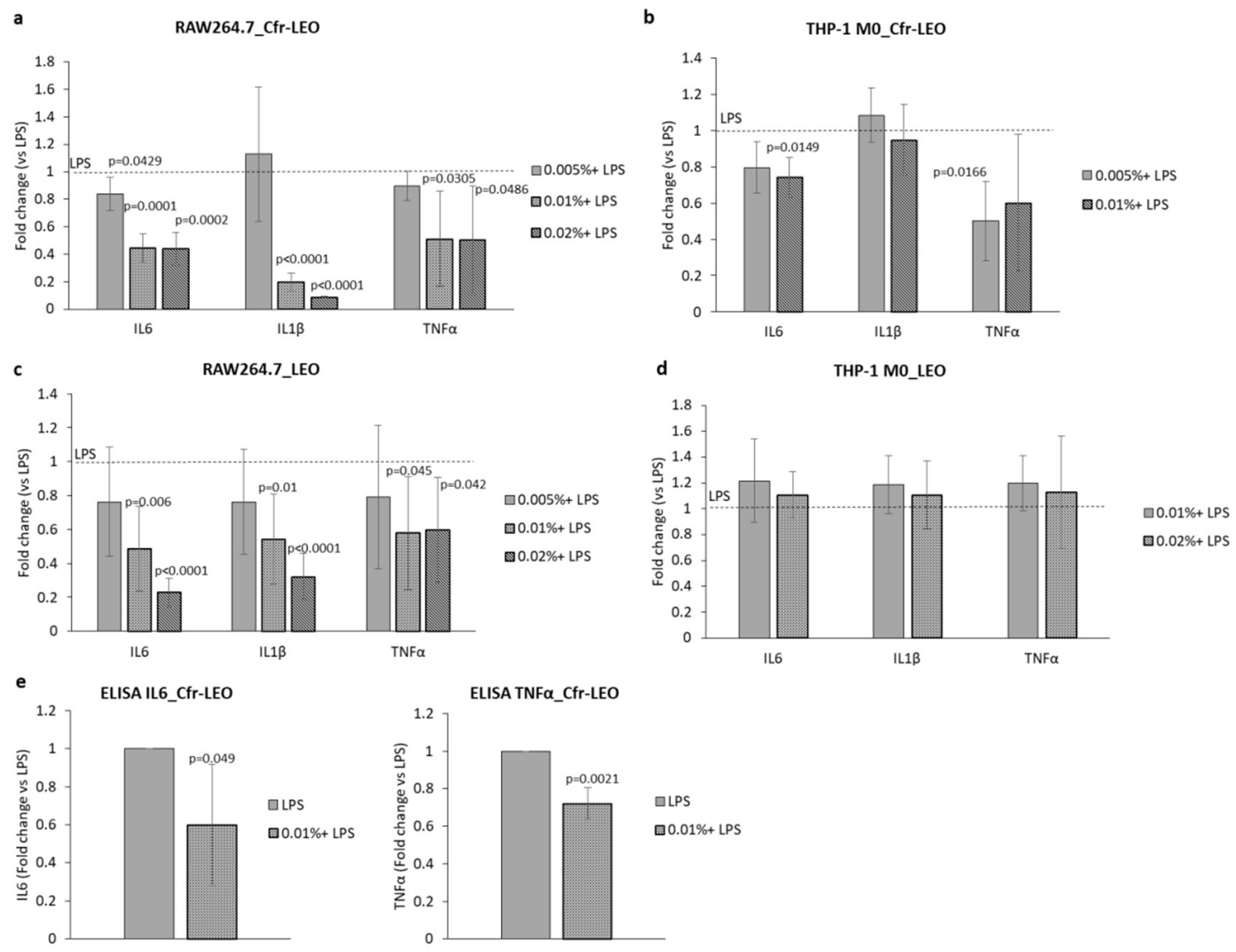

Figure 4. Anti-inflammatory effects of Cfr-LEO and LEO on LPS-activated macrophages. The anti-inflammatory effects of Cfr-LEO and LEO treatment on IL6, IL1b, and TNF $\alpha$ transcription levels were assessed by qRT-PCR analyses. (a) RAW264.7 cells were treated for $2 \mathrm{~h}$ with Cfr-LEO $(0.005 \%, 0.01 \%, 0.02 \%)$ and then exposed to LPS for $6 \mathrm{~h}$. Values are the mean \pm SD of three biological replicates. (b) THP-1 M0 were treated for $2 \mathrm{~h}$ with Cfr-LEO $(0.005 \%, 0.01 \%)$ and then exposed to LPS for $6 \mathrm{~h}$. Values are reported as Fold change versus cells treated with LPS (dashed line). Values are the mean \pm SD of three biological replicates for IL6 and TNF $\alpha$ of five biological replicates for IL1 $\beta$. The statistical significance of the differences between two groups (cells treated with LPS Vs cells 
pre-treated with Cfr-LEO + LPS) was analyzed using a two-tailed Student's $t$-test. (c) RAW264.7 cells were treated for $2 \mathrm{~h}$ with LEO $(0.005 \%, 0.01 \%, 0.02 \%)$ and then exposed to LPS for $6 \mathrm{~h}$. (d) THP-1 M0 were treated for $2 \mathrm{~h}$ with LEO $(0.005 \%, 0.01 \%)$ and then exposed to LPS for $6 \mathrm{~h}$. Values are reported as Fold change versus cells treated with LPS (dashed line). Values are the mean \pm SD of three to six biological replicates The statistical significance of the differences between two groups (cell treated with LPS Vs cells pre-treated with LEO + LPS) was analyzed using a two-tailed Student's t-test. (e) IL6 and $\mathrm{TNF} \alpha$ protein levels were measured by ELISA in the conditioned medium of RAW264.7 cells treated for $2 \mathrm{~h}$ with Cfr-LEO (0.01\%) and then exposed to LPS for $6 \mathrm{~h}$. Values are plotted as Fold change versus cell treated with LPS. Values are the mean \pm SD of three biological replicates. The statistical significance of the differences between the two groups (cells treated with LPS Vs cells pre-treated with Cfr-LEO + LPS) was analyzed using a one-tailed Student's $t$-test.

Overall, these data demonstrated that the pre-treatment of macrophages with Cfr-LEO reduces the expression of the pro-inflammatory cytokines TNF- $\alpha$, IL-1 $\beta$, and IL-6 induced by LPS. Interestingly, since the assays we have described were performed by using both Cfr-LEO and whole LEO, we can conclude that the enrichment in citral does not alter the well-known anti-inflammatory properties of the whole LEO [22,49].

According to the literature, chronic inflammation is associated with the phenomenon of oxidative stress, caused by the imbalance between the production of reactive oxygen species and the activities of defense systems [53]. EOs are described as natural antioxidant compounds since they exert protective effects by increasing the cellular GSH levels [54] and the GSH/GSSG ratio [55]. In view of these effects, the combined administration of EOs with drugs already used in clinics may reduce the toxic effects produced by therapeutics. For example, EOs from fennel, clove, and cumin reduced the hepatotoxic effects of cyclophosphamide also by increasing GSH levels [54].

Here we also evaluated the capability of Cfr-LEO to contrast the oxidant effects of LPS in human macrophages by performing the GSH/GSSG assay. GSH/GSSG is considered a key indicator of oxidative stress $[56,57]$. In particular, the increase in the ratio indicates a decrease in cellular oxidative stress [58-60]. As shown in Figure 5, we found that in LPS-treated THP1 M0 cells the pre-treatment for $2 \mathrm{~h}$ with Cfr-LEO induced the increase of the GSH/GSSG ratio compared to no pre-treated cells, indicating the ability of Cfr-LEO to counteract the LPS-induced oxidative stress.

Overall, these results suggest that Cfr-LEO can elicit anti-inflammatory and anti-oxidant activities in LPS-stimulated macrophages, providing a rationale to consider its potential role of protective agent against inflammation stimuli.

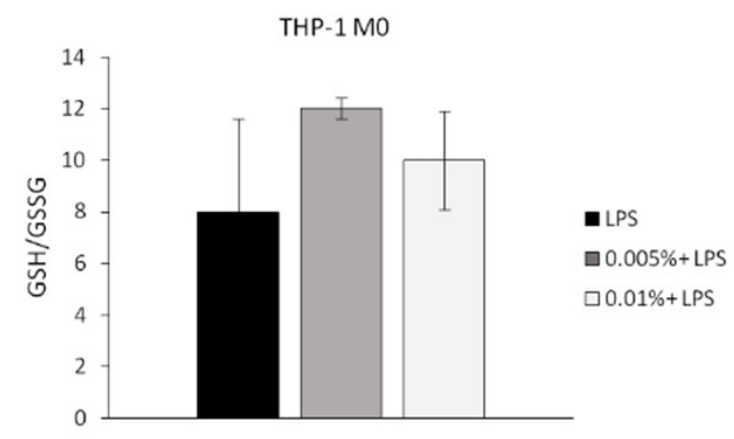

Figure 5. Anti-oxidant effect of Cfr-LEO. The anti-oxidant effects of Cfr-LEO treatment $(0.005 \%, 0.01 \%)$ was evaluated by GSH/GSSG-Glo Assay. THP-1 M0 were treated for $2 \mathrm{~h}$ with Cfr-LEO $(0.005 \%, 0.01 \%)$ and then exposed to LPS for $6 \mathrm{~h}$. Values are expressed as the GSH/GSSG ratio, calculated as follows: GSH/GSSG ratio = (Net total glutathione RLU-Net GSSG RLU)/(Net GSSG RLU/2). Values are the mean \pm SD of 2 independent experiments. 


\section{Conclusions}

To date, the interest of the nutraceutical industry is to use natural compounds that possess both biological and organoleptic properties, conferred for example by citral enrichment. Therefore, in this study, we have selected and mixed four fractions with analogous composition, showing enrichment in citral, and we highlighted their beneficial properties.

In conclusion, we demonstrated that the mix of the four citral-enriched fractions of lemon essential oil (Cfr-LEO), reduces the expression of pro-inflammatory mediators and decreases oxidative stress in murine as well as human macrophage cells. Therefore, having evaluated its non-toxicity and beneficial properties, we suggest that Cfr-LEO, which can certainly be applied in the agri-food industry because of its organoleptic properties, can also represent a preventive tool for improving human health.

Supplementary Materials: The following are available online at http://www.mdpi.com/2304-8158/9/9/1290/s1, Figure S1: Evaluation of the reproducibility of the fractionation process. (a) The analysis of the coefficient of variation $(\mathrm{CV} \%)$ for the three replicates. (b) Graph showing the percentage of each compound in the four examined fractions. Each point represents the mean \pm SD of the three independent replicates of the fractionation process. (c) The histogram represents the mean $\pm \mathrm{SD}$ of the percentage of citral in the selected fractions. Values are the mean of three independent replicates of the fractionation process.

Author Contributions: Experimental planning and data interpretations, S.F., M.P., S.R., and R.A.; experimental execution, M.P., S.R., C.Z., V.T., M.M., and G.A.; writing—original draft preparation, M.P. and S.R.; writing-review and editing, S.F., V.C., A.C., and R.A.; funding acquisition, V.C. and R.A. All authors have read and agreed to the published version of the manuscript.

Funding: This study was funded by a grant to Riccardo Alessandro and to Agrumaria Corleone s.p.a.: "Salute in tazza: innovative soluzioni per l'isolamento e l'applicazione industriale, anche in capsule, di composti biofunzionali ottenuti da agrumi di Sicilia" -PON I\&C - MISE F/050039/01-03/X32. Marzia Pucci is supported by an AIRC fellowship (project $n^{\circ} 22542$ ). Stefania Raimondo is supported by PON "Ricerca e Innovazione" 2014-2020-Azione 1.2 459 "Mobilità dei Ricercatori"-AIM “Attraction and International Mobility".

Conflicts of Interest: The authors declare no conflict of interest. The funders had no role in the design of the study; in the collection, analyses, or interpretation of data; in the writing of the manuscript; or in the decision to publish the results.

\section{References}

1. Tongnuanchan, P.; Benjakul, S. Essential oils: Extraction, bioactivities, and their uses for food preservation. J. Food Sci. 2014, 79, R1231-R1249. [CrossRef]

2. Jeliazkova, E.; Zheljazkov, V.D.; Kacaniova, M.; Astatkie, T.; Tekwani, B.L. Sequential elution of essential oil constituents during steam distillation of hops (humulus lupulus 1.) and influence on oil yield and antimicrobial activity. J. Oleo Sci. 2018, 67, 871-883. [CrossRef] [PubMed]

3. Celano, R.; Piccinelli, A.L.; Pagano, I.; Roscigno, G.; Campone, L.; De Falco, E.; Russo, M.; Rastrelli, L. Oil distillation wastewaters from aromatic herbs as new natural source of antioxidant compounds. Food Res. Int. 2017, 99, 298-307. [CrossRef] [PubMed]

4. Klimek-Szczykutowicz, M.; Szopa, A.; Ekiert, H. Citrus limon (lemon) phenomenon-a review of the chemistry, pharmacological properties, applications in the modern pharmaceutical, food, and cosmetics industries, and biotechnological studies. Plants 2020, 9, 119. [CrossRef]

5. Russo, M.; Bonaccorsi, I.; Costa, R.; Trozzi, A.; Dugo, P.; Mondello, L. Reduced time hplc analyses for fast quality control of citrus essential oils. J. Essent. Oil Res. 2015, 27, 307-315. [CrossRef]

6. Kaskoos, R.A. Essential oil analysis by gc-ms and analgesic activity of lippia citriodora and citrus limon. J. Essent. Oil Bear. Plants 2019, 22, 273-281. [CrossRef]

7. Gonzalez-Molina, E.; Dominguez-Perles, R.; Moreno, D.A.; Garcia-Viguera, C. Natural bioactive compounds of citrus limon for food and health. J. Pharm. Biomed. Anal. 2010, 51, 327-345. [CrossRef]

8. Gamarra, F.M.C.; Sakanaka, L.S.; Tambourgi, E.B.; Cabral, F.A. Influence on the quality of essential lemon (citrus aurantifolia) oil by distillation process. Braz. J. Chem. Eng. 2006, 23, 147-151. [CrossRef]

9. Luyendyk, J.P.; Kassel, K.M.; Allen, K.; Guo, G.L.; Li, G.; Cantor, G.H.; Copple, B.L. Fibrinogen deficiency increases liver injury and early growth response-1 (egr-1) expression in a model of chronic xenobiotic-induced cholestasis. Am. J. Pathol. 2011, 178, 1117-1125. [CrossRef] 
10. Hirota, R.; Roger, N.N.; Nakamura, H.; Song, H.S.; Sawamura, M.; Suganuma, N. Anti-inflammatory effects of limonene from yuzu (citrus junos tanaka) essential oil on eosinophils. J. Food Sci. 2010, 75, H87-H92. [CrossRef]

11. Peana, A.T.; Rubattu, P.; Piga, G.G.; Fumagalli, S.; Boatto, G.; Pippia, P.; De Montis, M.G. Involvement of adenosine a1 and a2a receptors in (-)-linalool-induced antinociception. Life Sci. 2006, 78, 2471-2474. [CrossRef] [PubMed]

12. Baik, J.S.; Kim, S.S.; Lee, J.A.; Oh, T.H.; Kim, J.Y.; Lee, N.H.; Hyun, C.G. Chemical composition and biological activities of essential oils extracted from korean endemic citrus species. J. Microbiol. Biotechnol. 2008, 18, 74-79. [PubMed]

13. Katsukawa, M.; Nakata, R.; Takizawa, Y.; Hori, K.; Takahashi, S.; Inoue, H. Citral, a component of lemongrass oil, activates pparalpha and gamma and suppresses cox-2 expression. Biochim. Biophys. Acta 2010, 1801, 1214-1220. [CrossRef] [PubMed]

14. Bouzenna, H.; Hfaiedh, N.; Giroux-Metges, M.A.; Elfeki, A.; Talarmin, H. Biological properties of citral and its potential protective effects against cytotoxicity caused by aspirin in the iec- 6 cells. Biomed. Pharmacother. 2017, 87, 653-660. [CrossRef] [PubMed]

15. Bhalla, Y.; Gupta, V.K.; Jaitak, V. Anticancer activity of essential oils: A review. J. Sci. Food Agric. 2013, 93, 3643-3653. [CrossRef]

16. Puatanachokchai, R.; Kishida, H.; Denda, A.; Murata, N.; Konishi, Y.; Vinitketkumnuen, U.; Nakae, D. Inhibitory effects of lemon grass (cymbopogon citratus, stapf) extract on the early phase of hepatocarcinogenesis after initiation with diethylnitrosamine in male fischer 344 rats. Cancer Lett. 2002, 183, 9-15. [CrossRef]

17. Balusamy, S.R.; Perumalsamy, H.; Veerappan, K.; Huq, M.A.; Rajeshkumar, S.; Lakshmi, T.; Kim, Y.J. Citral induced apoptosis through modulation of key genes involved in fatty acid biosynthesis in human prostate cancer cells: In silico and in vitro study. Biomed. Res. Int. 2020, 2020, 6040727. [CrossRef]

18. Moreno-Macias, H.; Romieu, I. Effects of antioxidant supplements and nutrients on patients with asthma and allergies. J. Allergy Clin. Immunol. 2014, 133, 1237-1244, Quiz 1245. [CrossRef]

19. Van Dyke, T.E.; van Winkelhoff, A.J. Infection and inflammatory mechanisms. J. Clin. Periodontol. 2013, 40 (Suppl. S14), S1-S7.

20. Yoon, W.J.; Lee, N.H.; Hyun, C.G. Limonene suppresses lipopolysaccharide-induced production of nitric oxide, prostaglandin e2, and pro-inflammatory cytokines in raw 264.7 macrophages. J. Oleo Sci. 2010, 59, 415-421. [CrossRef]

21. Shen, C.Y.; Jiang, J.G.; Zhu, W.; Ou-Yang, Q. Anti-inflammatory effect of essential oil from citrus aurantium 1. Var. Amara engl. J. Agric. Food Chem. 2017, 65, 8586-8594. [CrossRef] [PubMed]

22. Amorim, J.L.; Simas, D.L.; Pinheiro, M.M.; Moreno, D.S.; Alviano, C.S.; da Silva, A.J.; Fernandes, P.D. Anti-inflammatory properties and chemical characterization of the essential oils of four citrus species. PLoS ONE 2016, 11, e0153643. [CrossRef] [PubMed]

23. Ben Hsouna, A.; Gargouri, M.; Dhifi, W.; Ben Saad, R.; Sayahi, N.; Mnif, W.; Saibi, W. Potential anti-inflammatory and antioxidant effects of citrus aurantium essential oil against carbon tetrachloride-mediated hepatotoxicity: A biochemical, molecular and histopathological changes in adult rats. Environ. Toxicol. 2019, 34, 388-400. [CrossRef] [PubMed]

24. Bouzenna, H.; Samout, N.; Dhibi, S.; Mbarki, S.; Akermi, S.; Khdhiri, A.; Elfeki, A.; Hfaiedh, N. Protective effect of essential oil from citrus limon against aspirin-induced toxicity in rats. Hum. Exp. Toxicol. 2019, 38, 499-509. [CrossRef]

25. Wang, L.; Zhang, Y.; Fan, G.; Ren, J.N.; Zhang, L.L.; Pan, S.Y. Effects of orange essential oil on intestinal microflora in mice. J. Sci. Food Agric. 2019, 99, 4019-4028. [CrossRef]

26. Moraes, T.M.; Rozza, A.L.; Kushima, H.; Pellizzon, C.H.; Rocha, L.R.; Hiruma-Lima, C.A. Healing actions of essential oils from citrus aurantium and d-limonene in the gastric mucosa: The roles of vegf, pcna, and cox-2 in cell proliferation. J. Med. Food 2013, 16, 1162-1167. [CrossRef]

27. Kang, P.; Suh, S.H.; Min, S.S.; Seol, G.H. The essential oil of citrus bergamia risso induces vasorelaxation of the mouse aorta by activating $\mathrm{k}(+)$ channels and inhibiting ca(2+) influx. J. Pharm. Pharmacol. 2013, 65, 745-749. [CrossRef] 
28. Kang, P.; Ryu, K.H.; Lee, J.M.; Kim, H.K.; Seol, G.H. Endothelium- and smooth muscle-dependent vasodilator effects of citrus aurantium 1. Var. Amara: Focus on ca(2+) modulation. Biomed. Pharmacother. 2016, 82, 467-471. [CrossRef]

29. Oboh, G.; Olasehinde, T.A.; Ademosun, A.O. Essential oil from lemon peels inhibit key enzymes linked to neurodegenerative conditions and pro-oxidant induced lipid peroxidation. J. Oleo Sci. 2014, 63, 373-381. [CrossRef]

30. Costa, C.A.; Cury, T.C.; Cassettari, B.O.; Takahira, R.K.; Florio, J.C.; Costa, M. Citrus aurantium 1. Essential oil exhibits anxiolytic-like activity mediated by 5 -ht(1a)-receptors and reduces cholesterol after repeated oral treatment. BMC Complement. Altern. Med. 2013, 13, 42. [CrossRef]

31. Zhang, L.L.; Yang, Z.Y.; Fan, G.; Ren, J.N.; Yin, K.J.; Pan, S.Y. Antidepressant-like effect of citrus sinensis (1.) osbeck essential oil and its main component limonene on mice. J. Agric. Food Chem. 2019, 67, 13817-13828. [CrossRef] [PubMed]

32. Frolova, N.; Ukrainets, A.; Sylka, I.; Nemirich, A.; Kuzmin, O. Separation of terpenes from lemon essential oil by selective fractionation under a vacuum. East. Eur. J. Enterp. Technol. 2019, 2, 32-36. [CrossRef]

33. Warsito, W.; Palungan, M.H.; Utomo, E.P. Profiling study of the major and minor components of kaffir lime oil (citrus hystrix dc.) in the fractional distillation process. Pan Afr. Med. J. 2017, 27, 282. [CrossRef] [PubMed]

34. Kapsaski-Kanelli, V.N.; Evergetis, E.; Michaelakis, A.; Papachristos, D.P.; Myrtsi, E.D.; Koulocheri, S.D.; Haroutounian, S.A. "Gold" pressed essential oil: An essay on the volatile fragment from citrus juice industry by-products chemistry and bioactivity. Biomed. Res. Int. 2017, 2017, 2761461. [CrossRef] [PubMed]

35. Mehl, F.; Marti, G.; Boccard, J.; Debrus, B.; Merle, P.; Delort, E.; Baroux, L.; Raymo, V.; Velazco, M.I.; Sommer, H.; et al. Differentiation of lemon essential oil based on volatile and non-volatile fractions with various analytical techniques: A metabolomic approach. Food Chem. 2014, 143, 325-335. [CrossRef] [PubMed]

36. Dugo, P.; Ragonese, C.; Russo, M.; Sciarrone, D.; Santi, L.; Cotroneo, A.; Mondello, L. Sicilian lemon oil: Composition of volatile and oxygen heterocyclic fractions and enantiomeric distribution of volatile components. J. Sep. Sci. 2010, 33, 3374-3385. [CrossRef]

37. Lu, Q.; Huang, N.; Peng, Y.; Zhu, C.; Pan, S. Peel oils from three citrus species: Volatile constituents, antioxidant activities and related contributions of individual components. J. Food Sci. Technol. 2019, 56, 4492-4502. [CrossRef]

38. Navarra, M.; Ferlazzo, N.; Cirmi, S.; Trapasso, E.; Bramanti, P.; Lombardo, G.E.; Minciullo, P.L.; Calapai, G.; Gangemi, S. Effects of bergamot essential oil and its extractive fractions on sh-sy5y human neuroblastoma cell growth. J. Pharm. Pharmacol. 2015, 67, 1042-1053. [CrossRef]

39. Hu, W.; Zhang, N.; Chen, H.; Zhong, B.; Yang, A.; Kuang, F.; Ouyang, Z.; Chun, J. Fumigant activity of sweet orange essential oil fractions against red imported fire ants (hymenoptera: Formicidae). J. Econ. Entomol. 2017, 110, 1556-1562. [CrossRef]

40. Shiratori, H.; Feinweber, C.; Luckhardt, S.; Linke, B.; Resch, E.; Geisslinger, G.; Weigert, A.; Parnham, M.J. Thp-1 and human peripheral blood mononuclear cell-derived macrophages differ in their capacity to polarize in vitro. Mol. Immunol. 2017, 88, 58-68. [CrossRef]

41. Raimondo, S.; Naselli, F.; Fontana, S.; Monteleone, F.; Lo Dico, A.; Saieva, L.; Zito, G.; Flugy, A.; Manno, M.; Di Bella, M.A.; et al. Citrus limon-derived nanovesicles inhibit cancer cell proliferation and suppress $\mathrm{cml}$ xenograft growth by inducing trail-mediated cell death. Oncotarget 2015, 6, 19514-19527. [CrossRef] [PubMed]

42. Danial, N.N. Bcl-2 family proteins: Critical checkpoints of apoptotic cell death. Clin. Cancer Res. 2007, 13, 7254-7263. [CrossRef] [PubMed]

43. Rea, I.M.; Gibson, D.S.; McGilligan, V.; McNerlan, S.E.; Alexander, H.D.; Ross, O.A. Age and age-related diseases: Role of inflammation triggers and cytokines. Front. Immunol. 2018, 9, 586. [CrossRef]

44. Chung, H.Y.; Kim, D.H.; Lee, E.K.; Chung, K.W.; Chung, S.; Lee, B.; Seo, A.Y.; Chung, J.H.; Jung, Y.S.; Im, E.; et al. Redefining chronic inflammation in aging and age-related diseases: Proposal of the senoinflammation concept. Aging Dis. 2019, 10, 367-382. [CrossRef] [PubMed]

45. Aiello, A.; Farzaneh, F.; Candore, G.; Caruso, C.; Davinelli, S.; Gambino, C.M.; Ligotti, M.E.; Zareian, N.; Accardi, G. Immunosenescence and its hallmarks: How to oppose aging strategically? A review of potential options for therapeutic intervention. Front. Immunol. 2019, 10, 2247. [CrossRef] 
46. Xia, S.; Zhang, X.; Zheng, S.; Khanabdali, R.; Kalionis, B.; Wu, J.; Wan, W.; Tai, X. An update on inflamm-aging: Mechanisms, prevention, and treatment. J. Immunol. Res. 2016, 2016, 8426874. [CrossRef]

47. Franceschi, C.; Bonafe, M.; Valensin, S.; Olivieri, F.; De Luca, M.; Ottaviani, E.; De Benedictis, G. Inflamm-aging. An evolutionary perspective on immunosenescence. Ann. NY Acad. Sci. 2000, 908, 244-254. [CrossRef]

48. Plastina, P.; Apriantini, A.; Meijerink, J.; Witkamp, R.; Gabriele, B.; Fazio, A. In vitro anti-inflammatory and radical scavenging properties of chinotto (citrus myrtifolia raf.) essential oils. Nutrients 2018, 10, 783. [CrossRef]

49. Kim, K.N.; Ko, Y.J.; Yang, H.M.; Ham, Y.M.; Roh, S.W.; Jeon, Y.J.; Ahn, G.; Kang, M.C.; Yoon, W.J.; Kim, D.; et al. Anti-inflammatory effect of essential oil and its constituents from fingered citron (citrus medica 1 . Var. Sarcodactylis) through blocking jnk, erk and nf-kappab signaling pathways in lps-activated raw 264.7 cells. Food Chem. Toxicol. 2013, 57, 126-131. [CrossRef]

50. Kiefer, R.; Kieseier, B.C.; Stoll, G.; Hartung, H.P. The role of macrophages in immune-mediated damage to the peripheral nervous system. Prog. Neurobiol. 2001, 64, 109-127. [CrossRef]

51. Mantovani, A.; Allavena, P.; Sica, A.; Balkwill, F. Cancer-related inflammation. Nature 2008, 454, $436-444$. [CrossRef] [PubMed]

52. Elinav, E.; Nowarski, R.; Thaiss, C.A.; Hu, B.; Jin, C.; Flavell, R.A. Inflammation-induced cancer: Crosstalk between tumours, immune cells and microorganisms. Nat. Rev. Cancer 2013, 13, 759-771. [CrossRef] [PubMed]

53. Cannizzo, E.S.; Clement, C.C.; Sahu, R.; Follo, C.; Santambrogio, L. Oxidative stress, inflamm-aging and immunosenescence. J. Proteom. 2011, 74, 2313-2323. [CrossRef] [PubMed]

54. Sheweita, S.A.; El-Hosseiny, L.S.; Nashashibi, M.A. Protective effects of essential oils as natural antioxidants against hepatotoxicity induced by cyclophosphamide in mice. PLoS ONE 2016, 11, e0165667. [CrossRef]

55. Porres-Martinez, M.; Gonzalez-Burgos, E.; Carretero, M.E.; Gomez-Serranillos, M.P. Protective properties of salvia lavandulifolia vahl. Essential oil against oxidative stress-induced neuronal injury. Food Chem. Toxicol. 2015, 80, 154-162. [CrossRef]

56. Ho, E.; Karimi Galougahi, K.; Liu, C.C.; Bhindi, R.; Figtree, G.A. Biological markers of oxidative stress: Applications to cardiovascular research and practice. Redox Biol. 2013, 1, 483-491. [CrossRef]

57. Valko, M.; Leibfritz, D.; Moncol, J.; Cronin, M.T.; Mazur, M.; Telser, J. Free radicals and antioxidants in normal physiological functions and human disease. Int. J. Biochem. Cell Biol. 2007, 39, 44-84. [CrossRef]

58. Balkrishna, A.; Solleti, S.K.; Singh, H.; Tomer, M.; Sharma, N.; Varshney, A. Calcio-herbal formulation, divya-swasari-ras, alleviates chronic inflammation and suppresses airway remodelling in mouse model of allergic asthma by modulating pro-inflammatory cytokine response. Biomed. Pharmacother. 2020, 126, 110063. [CrossRef]

59. Sousa, M.S.B.; Holanda, I.M.S.; Monteiro, H.M.C.; Amancio-Dos-Santos, A. Antioxidant extract counteracts the effects of aging on cortical spreading depression and oxidative stress in the brain cortex. Acta Cir. Bras. 2018, 33, 472-482. [CrossRef]

60. Ni, J.; Wang, Q.; Shah, F.A.; Liu, W.; Wang, D.; Huang, S.; Fu, S.; Wu, L. Exogenous melatonin confers cadmium tolerance by counterbalancing the hydrogen peroxide homeostasis in wheat seedlings. Molecules 2018, 23, 799. [CrossRef]

(C) 2020 by the authors. Licensee MDPI, Basel, Switzerland. This article is an open access article distributed under the terms and conditions of the Creative Commons Attribution (CC BY) license (http://creativecommons.org/licenses/by/4.0/). 